\title{
Crystal Structure of 1-(4-Acetylamidophenyl)-3-(4-carboxyphenyl)triazene
}

\author{
Carlos Henrique Oliveira do Amaral, ** Rosmari Hörner, ${ }^{*}$ Luiz Gustavo Brenner ReEtz,* \\ Leandro Renato Simon de CAMARgo, ${ }^{* *}$ Flávia Cavalieri MACHADo, ${ }^{* * *}$ and Manfredo Hörner**†
}

\author{
* Departamento de Análises Clínicas e Toxicológicas, Universidade Federal de Santa Maria, 97105-970 \\ Santa Maria, RS, Brazil \\ **Departamento de Química, Universidade Federal de Santa Maria, Cx. Postal 5031, 97110-900 Santa \\ Maria, RS, Brazil \\ ***Departamento de Química, Instituto de Ciências Exatas, Universidade Federal de Juiz de Fora, 36036-330 \\ Juiz de Fora, MG, Brazil
}

\begin{abstract}
The crystal structure of the title compound, $\mathrm{C}_{15} \mathrm{H}_{14} \mathrm{~N}_{4} \mathrm{O}_{3}$, reveals the expected trans stereochemistry about the N=N double bond in the diazoamine moiety. The interplanar angle $\left[36.68(6)^{\circ}\right]$ between the terminal phenyl rings indicates that the whole molecule deviates significantly from planarity (r.m.s. deviation $=0.3148 \AA$ ). Intermolecular $\mathrm{O}-\mathrm{H} \cdots \mathrm{O}$ classical hydrogen bonds, and hydrogen bonds with a bifurcated geometry generate a three-dimensional molecule arrangement. The distribution of the double-bond character among the $\mathrm{N}$ atoms of the diazoamine moiety is unequal, indicating a delocalization of the $\pi$ electrons over the $\mathrm{N}=\mathrm{N}-\mathrm{N}(\mathrm{H})$ group toward the terminal 4-carboxyphenyl substituent.
\end{abstract}

(Received November 30, 2007; Accepted January 7, 2008; Published on web May 16, 2008)

As part of a study of molecular associations through hydrogen bonds in the solid state of asymmetric disubstituted 1,3diaryltriazenes that present biological activity, we report on the crystal structure of the title molecule, (I), (Fig. 1) based on a single-crystal X-ray structural analysis.

The synthesis of the title complex included reagents and solvents of reagent grade, which were used without further purification. 4-carboxyphenylamine $(0.50 \mathrm{~g}, 3.65 \mathrm{mmol})$ was dissolved in a $50 \%$ aqueous solution of $\mathrm{HCl}(30 \mathrm{~mL})$ and cooled to $-5^{\circ} \mathrm{C}$. A sodium nitrite solution $(0.30 \mathrm{~g}, 4.38 \mathrm{mmol})$ in water $(20 \mathrm{~mL})$ was slowly added with continuous stirring. A solution of 4-acetylamidophenylamine $(0.55 \mathrm{~g}, 3.65 \mathrm{mmol})$ in $50 \%$ aqueous glacial acetic acid $(30 \mathrm{~mL})$ was added slowly to the reaction mixture. Stirring was continued for $30 \mathrm{~min}$ at $-5^{\circ} \mathrm{C}$. The resulting mixture was neutralized with a $10 \%$ aqueous solution of $\mathrm{NaHCO}_{3}$. A crude dark-red precipitate was separated by filtration and washed with small portions of cool water. The product was dried over $\mathrm{P}_{2} \mathrm{O}_{5}$ under vacuum, and recrystallized from a methanol/acetone mixture (1:1). Dark-red bar-shaped crystals of (I), suitable for X-ray analysis, were obtained by slow evaporation of the solvent mixture. Yield, $60 \%(0,66 \mathrm{~g}$, $2.20 \mathrm{mmol}$ ), based on 4-acetylamidophenylamine; m.p., 146 $148^{\circ} \mathrm{C}$. IR ( $\mathrm{KBr}$ pellet, $\left.\mathrm{cm}^{-1}\right), 3380\left(v_{\text {as }} \mathrm{N}-\mathrm{H}\right) \mathrm{s} ; 1698[\mathrm{v}(\mathrm{C}=\mathrm{O})$, acetylamido-group $] \mathrm{vs} ; 1610$ [ $\mathrm{v}(\mathrm{C}=\mathrm{O})$, carboxyl-group $] \mathrm{vs} ; 1405$ $\left(v_{\mathrm{s}} \mathrm{N}=\mathrm{N}\right) \mathrm{s} ; 1186\left(v_{\mathrm{s}} \mathrm{N}-\mathrm{N}\right) \mathrm{s}$. (IR data: vs, very strong; s, strong). Anal. Calcd for $\mathrm{C}_{15} \mathrm{H}_{14} \mathrm{~N}_{4} \mathrm{O}_{3}$ : C, 60.40; H, 4.73; N, 18.78. Found C, 60.32; H, 4.23; N, 19.15.

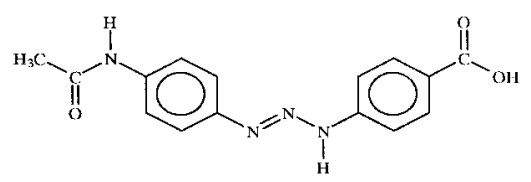

Fig. 1 Structural chemical diagram of (I).

$\uparrow$ To whom correspondence should be addressed.

E-mail: hoerner@smail.ufsm.br
Compound (I) showed activity against the Gram-positive bacteria Staphylococus epidermidis (MIC $=64 \mu \mathrm{g} / \mathrm{mL}$ ) and Rhodococcus spp. (MIC $=64 \mu \mathrm{g} / \mathrm{mL}$ ), and against the Gramnegative bacteria Enterobacter cloacae $(\mathrm{MIC}=32 \mu \mathrm{g} / \mathrm{mL})$.

Data were collected with a Bruker APEX II CCD area-detector diffractometer and graphite-monochromatized Mo- $K_{\alpha}$ radiation $(\lambda=0.71073 \AA)$. The crystal and experimental data are listed in Table 1 . The structure was solved by direct methods using SIR2004. ${ }^{2}$ The non-hydrogen atoms were refined anisotropically by the full-matrix least-square method using SHELXL97. ${ }^{3}$ The

Table 1 Crystal and experimental data

Formula: $\mathrm{C}_{15} \mathrm{H}_{14} \mathrm{~N}_{4} \mathrm{O}_{3}$

Formula weight: 298.30

Crystal system: monoclinic

Space group: $P 2_{1} / n \quad Z=4$

$a=7.77230(10) \AA$

$b=9.7365(2) \AA$

$c=19.3554(3) \AA$

$V=1462.09(4) \AA^{3}$

$D_{\mathrm{x}}=1.355 \mathrm{~g} / \mathrm{cm}^{3}$

Absorption coefficient $=0.098 \mathrm{~mm}^{-1}$

$F\left(\begin{array}{lll}0 & 0 & 0\end{array}\right)=624$

Crystal dimensions $(\mathrm{mm})=0.32 \times 0.28 \times 0.19$

$R=0.0394$

$R w=0.1093$

$\theta$ range for data collection: 2.89 to $25.50^{\circ}$

Completeness to $\theta=25.50^{\circ} 99.9 \%$

Goodness-of-fit $=1.038$

$(\Delta \rho)_{\max }=0.227 \mathrm{e} . \AA^{-3}$

$(\Delta \rho)_{\min }=-0.207$ e. $\AA^{-3}$

No. of reflections used $=3283$

No. of parameters $=256$

Data collection: COSMO/APEX2; Bruker, $2004^{8}$

Cell refinement and data reduction: SAINT; Bruker, $2004^{8}$

Absorption correction: multi-scan (SADABS; Bruker, 2004) ${ }^{8}$

Molecular graphics: DIAMOND

CCDC 669265 
Table 2 Selected bond lengths $(\AA)$ and angles $\left({ }^{\circ}\right)$

\begin{tabular}{llll}
$\mathrm{C} 1-\mathrm{O} 1$ & $1.200(2)$ & $\mathrm{O} 1-\mathrm{C} 1-\mathrm{O} 2$ & $122.42(14)$ \\
$\mathrm{C} 1-\mathrm{C} 14$ & $1.479(2)$ & $\mathrm{C} 14-\mathrm{C} 1-\mathrm{O} 2$ & $114.44(13)$ \\
$\mathrm{C} 1-\mathrm{O} 2$ & $1.3110(19)$ & $\mathrm{N} 12-\mathrm{N} 11-\mathrm{C} 11$ & $119.83(12)$ \\
$\mathrm{N} 11-\mathrm{C} 11$ & $1.3922(18)$ & $\mathrm{N} 11-\mathrm{N} 12-\mathrm{N} 13$ & $112.46(12)$ \\
$\mathrm{N} 11-\mathrm{N} 12$ & $1.3357(17)$ & $\mathrm{N} 12-\mathrm{N} 13-\mathrm{C} 21$ & $112.60(11)$ \\
$\mathrm{N} 12-\mathrm{N} 13$ & $1.2660(17)$ & $\mathrm{C} 24-\mathrm{N} 4-\mathrm{C} 2$ & $126.11(13)$ \\
$\mathrm{N} 13-\mathrm{C} 21$ & $1.4290(18)$ & $\mathrm{N} 4-\mathrm{C} 2-\mathrm{O} 3$ & $122.17(13)$ \\
$\mathrm{N} 4-\mathrm{C} 24$ & $1.41955(18)$ & $\mathrm{N} 4-\mathrm{C} 2-\mathrm{C} 3$ & $116.05(13)$ \\
$\mathrm{N} 4-\mathrm{C} 2$ & $1.3408(19)$ & & \\
$\mathrm{C} 2-\mathrm{O} 3$ & $1.2328(18)$ & & \\
$\mathrm{C} 2-\mathrm{C} 3$ & $1.495(2)$ & & \\
\hline
\end{tabular}

positional parameters of the $\mathrm{H}$ atoms bonded to $\mathrm{C}$ atoms were obtained geometrically, with the $\mathrm{C}-\mathrm{H}$ distances fixed $(0.96 \AA$ for $\mathrm{C} s p^{3}$ and $0.93 \AA$ for $\mathrm{C} s p^{2}$ ), and refined as riding on their respective $\mathrm{C}$ atoms, with $U_{\text {iso }}(\mathrm{H})=1.5 U_{\text {eq }}\left(\mathrm{Csp}^{3}\right)$ and $U_{\text {iso }}(\mathrm{H})=$ $1.2 U_{\mathrm{eq}}\left(\mathrm{Css}^{2}\right)$. The positional parameters of atoms $\mathrm{H} 1, \mathrm{H} 2$ and $\mathrm{H} 3$ were obtained from a difference map and refinement with an isotropic displacement parameter. Selected bond distances and angles are given in Table 2. The molecular structure is shown in Fig. 2.

The molecular structure of (I) shows the characteristic trans stereochemistry about the $\mathrm{N}=\mathrm{N}$ double bond of the diazoamino group of free triazenes. Deviation observed from normal N-N and $\mathrm{C}_{\text {ary }}-\mathrm{N}$ bond length indicate a delocalization of the $\pi$ electrons on the triazene group towards to the terminal 4carboxyphenyl substituent of the $\mathrm{N}=\mathrm{N}-\mathrm{N}(\mathrm{H})$ moiety. The $\mathrm{N} 12=\mathrm{N} 13$ bond [1.2660(17) $\mathrm{A}]$ is longer than the typical value for a double bond (1.236 $\AA$ ), whereas the N11-N12 bond [1.3357(17) $\mathrm{A}]$ is shorter than the typical value for a single bond $(1.404 \AA) .{ }^{4}$ In addition, the C11-N11 [1.3922(18) $\left.\mathrm{A}\right]$ bond is shorter than the characteristic $\mathrm{N}-\mathrm{C}_{\text {aryl }}$ single bonds (secondary amines, $\left.R_{2} \mathrm{NH}, R=\mathrm{Cs} p^{2} ; 1.452 \AA\right) .{ }^{5}$ These values are in good agreement with those observed in a similar compound, 1,3bis(2,4-dibromophenyl)triazene, hereafter (II) $[\mathrm{N}=\mathrm{N}=$ 1.267(7) $\mathrm{A}, \mathrm{N}-\mathrm{N}=1.332(7) \AA, \mathrm{C}-\mathrm{N}=1.388(8) \AA]{ }^{6}$ As a consequence, the interplanar angles between the phenyl ring $\mathrm{C} 11 / \mathrm{C} 16$ and the N11-N12=N13 group [6.5 $\left.(2)^{\circ}\right]$, and the phenyl ring $\mathrm{C} 11 / \mathrm{C} 16$ and the $\mathrm{O} 2-\mathrm{C} 1(=\mathrm{O} 1)$ group of the carboxyl substituent $\left[3.5(3)^{\circ}\right]$, demonstrate that this part of the molecule is almost planar (r.m.s. $=0.0713 \AA$ ). On the other hand, the interplanar angles between the phenyl ring $\mathrm{C} 21 / \mathrm{C} 26$ and the N11-N12=N13 group [33.60 $(11)^{\circ}$ ], and the phenyl ring C21/C26 and the $\mathrm{N} 4-\mathrm{C} 2(=\mathrm{O} 3)-\mathrm{C} 3$ group $\left[35.71(7)^{\circ}\right]$ indicates that the delocalization of the $\pi$ electrons on the triazene group towards to the terminal 4-acetylamidophenyl substituent is hindered, and contributes to the lack of planarity of the whole molecule (r.m.s. deviation $=0.3148 \AA$ ). The bond angle of the $\mathrm{N}=\mathrm{N}-\mathrm{N}$ triad $\left[\mathrm{N} 11-\mathrm{N} 12-\mathrm{N} 13=112.46(12)^{\circ}\right]$ is close to that angle found in (II) $\left[111.6(5)^{\circ}\right] .^{6}$

Molecules of (I) related by an inversion center are associated by intermolecular hydrogen bonds with a bifurcated geometry, $\left(D_{1}-\mathrm{H}_{1}, D_{2}-\mathrm{H}_{2}\right) \cdots(A)$ ( $D$, donor atom; $A$, acceptor atom), (N4-

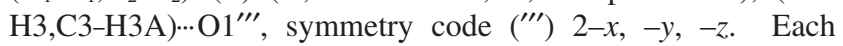
molecule of this centrossymetric pair generates another centrosymmetric dimer via a classical N11-H1N.N13' intermolecular hydrogen bond, symmetry code (') $1-x, 1-y,-z$. This resulting centrosymmetric assemblage is related by an axial $2_{1}$ screw axis along the [010] direction, generating an infinite two-dimensional array of molecules that expand to a three-

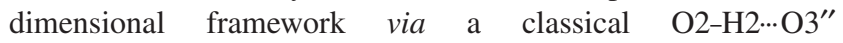
intermolecular hydrogen bond along the [100] direction, symmetry code (") $3 / 2+x, 1 / 2-y,-1 / 2+z$ (Table 3$)^{7}$

Beside the geometrical parameters mentioned in Table 3, the

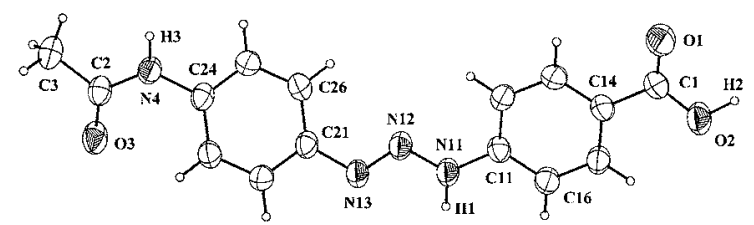

Fig. 2 Molecular structure of (I) with the atom-numbering scheme. Displacement ellipsoids are drawn at the 50\% probability level and $\mathrm{H}$ atoms have arbitrary radii.

Table 3 Hydrogen-bonding geometric parameters $\left(\AA{ }^{\circ}{ }^{\circ}\right)$

\begin{tabular}{lllll}
\hline & & & & \\
& $D-\mathrm{H} \cdots A$ & $\mathrm{H} \cdots A$ & $D \cdots A$ & $D-\mathrm{H} \cdots A$ \\
\hline $\mathrm{N} 11-\mathrm{H} 1 \cdots \mathrm{N}^{\prime} 3^{\prime}$ & $0.94(2)$ & $2.29(2)$ & $3.2205(18)$ & $169.2(16)$ \\
$\mathrm{O} 2-\mathrm{H} 2 \cdots 03^{\prime \prime}$ & $1.02(2)$ & $1.57(2)$ & $2.5895(16)$ & $172(2)$ \\
$\mathrm{N} 4-\mathrm{H} 3 \cdots 1^{\prime \prime}$ & $0.882(18)$ & $1.976(18)$ & $2.851(2)$ & $170.9(17)$ \\
$\mathrm{C} 3-\mathrm{H} 3 \mathrm{~A} \cdots \mathrm{O} 1^{\prime \prime \prime}$ & 0.96 & 2.58 & $3.420(2)$ & 147 \\
\hline (D= donor atom, $A=$ acceptor atom) & & &
\end{tabular}

Symmetry codes: (') $1-x, 1-y,-\bar{z},\left(\right.$ (') $3 / 2+x, 1 / 2-y,-1 / 2+z$, (") $\left.^{\prime \prime}\right) 2-x,-y_{4}-z$

angle $\mathrm{H} 3 \cdots \mathrm{O}^{\prime \prime \prime} \cdots \mathrm{H} 3 \mathrm{~A}$ is $53.4^{\circ}$, and the six-member ring, $\mathrm{H} 3 \mathrm{~A} \cdots \mathrm{O}^{\prime \prime \prime}{ }^{\prime \prime} . \mathrm{H} 3-\mathrm{N} 4-\mathrm{C} 2-\mathrm{C} 3$ observed in the centrosymmetric assemblage is almost planar (r.m.s. $=0.00485 \AA$ ).

The phenyl rings C11/C16 (r.m.s. deviation $0.0010 \AA$ ) and C21/C26 (r.m.s. deviation $0.0084 \AA$ ) are planar within the experimental error, and make an interplanar angle of $36.68(6)^{\circ}$ which demonstrates that the whole molecule deviates significantly from planarity.

\section{Acknowlegements}

This work received partial support from $\mathrm{CNPq}$ (proc. 477569/2006-4), and FAPERGS/PRONEX (Proc. 98/0451.6). M.H. thanks CNPq (proc. 309008/2006-9), and L.G.B.R. thanks $\mathrm{CNPq} / \mathrm{PIBIC}$ for grants. The diffractometer was supported by the Financiadora de Estudos e Projetos (FINEP, CT-Infra 03/2001).

\section{References}

1. J. C. McDonald, P. C. Dorrestein, and M. M. Pilley, Cryst. Growth \& Design, 2001, 1, 29, and references therein.

2. M. C. Burla, R. Caliandro, M. Camalli, B. Carrozzini, G. L. Cascarano, L. De Caro, C. Giacovazzo, G. Polidori, and R. Spagna, SIR2004, J. Appl. Cryst., 2005, 38, 381.

3. G. M. Sheldrick, SHELXL97, 1997, University of Göttingen, Germany.

4. F. H. Allen, O. Kennard, D. G. Watson, L. Brammer, A. G. Orpen, and R. Taylor, J. Chem. Soc. Perkin Trans. 1987, 2, S1; E. Teatum, K. Gschneidner, and J. Waber, Report LA2345. Los Alamos Scientific Laboratory, New Mexico, USA, 1960.

5. A. G. Orpen, L. Brammer, F. H. Allen, O. Kennard, D. G. Watson, and R. Taylor, J. Chem. Soc. Dalton Trans., 1989, S1.

6. M. Hörner, I. C. Casagrande, J. Bordinhão, and C. M. Mössmer, Acta Crystallogr., 2002, C58, o193.

7. A. L. Spek. PLATON-A Multipurpose Crystallographic Tool, Utrecht University, Utrecht, Tehe Netherlands, 2005.

8. Bruker AXS Inc., Madison, Wisconsin, USA, (C) 2005, COSMO (Version 1.48), SAINT (Version 7.06A), SADABS (Version 2.10).

9. K. Brandenburg. DIAMOND. 2004 - 2005, Version 3.1. Crystal Impact GbR, Bonn, Germany. 